\title{
Intravitreal injection of fibroblasts: the pathological effects on the ocular tissues of the rabbit following an intravitreal injection of autologous skin fibroblasts
}

\author{
CATHRYN A HITCHINS AND IAN GRIERSON
}

From the Pathology Department, Institute of Ophthalmology, London

SUMmARY The intravitreal injection of autologous cultured fibroblasts has been used by many응 groups to study proliferative vitreoretinopathy. Ninety-five New Zealand white rabbits were used to study the pathological effects on the ocular tissues following such an injection over various time? periods up to six months. The ocular tissues were studied by light microscopy, electron microscopy, immunohistochemistry, and autoradiography. The cells which contributed to the inflammatory $\infty$ response (initially neutrophils, then later macrophages and lymphocytes) were found to gain entry $\frac{\text { ? }}{2}$ into the vitreous via the pars plana, pars plicata, and the vessels associated with the optic nerve $\vec{c}$ head. In the experimental eyes the detached retinae had a reduced ability to incorporate ${ }^{3} \mathrm{H} \subseteq$ proline. Both epiretinal and subretinal membranes were found on the retinal surfaces. The majority of the glial cells within the membranes were identified as Müller cells. The retinal pigment $\stackrel{\infty}{\infty}$ epithelium beneath the detached retinae incorporated ${ }^{3} \mathrm{H}$ thymidine and detached into the ${ }^{\infty}$ subretinal space. Clear evidence was obtained of both epithelial cell migration through the retina and involvement within epiretinal membranes.

The intravitreal injection of tissue cultured autologous skin fibroblasts produces fibrous vitreal membranes which exert tractional forces leading to retinal detachment. ${ }^{1-7}$ The fibroblast injection procedure has been used by several groups to study the antiproliferative activity of drugs which may have value in the treatment of proliferative vitreoretinopathy. ${ }^{8-12}$ So far most of the morphological studies have centred on the organisation of the vitreal membranes, ${ }^{2+7}$ which are principally the product of the injected cells. ${ }^{5}$ Considerably less emphasis has been placed on the response of the retina, uvea, and other ocular tissues to the injection of cultured autologous fibroblasts into the vitreous.

Sugita $e t \mathrm{al}^{2}{ }^{2}$ were aware that the injection of autologous fibroblasts was associated with uveal inflammation. Although homologous fibroblast injection produces a biphasic response with plasma cells present in the second phase, autologous fibroblasts produce a non-immune reaction. ${ }^{5}$ Tano et al. ${ }^{1011}$ described retinal neovascularisation and we

Correspondence to Ian Grierson, PhD, Institute of Ophthalmology, 17/25 Cayton Street, London EC1V 9AT. observed retinal gliosis ${ }^{5}$ in the autologous model. The autologous cultured fibroblast injection model is worthwhile only if the proliferative and reactive processes within the rabbit eye can be related to the $\frac{0}{0}$. human situation. In the present study of autologous:fibroblast injection into the rabbit vitreous the patho- 3 logical changes within the retina and vitreous were examined by light microscopy, immunohistochemistry, autoradiography, and transmission and $\circ$ scanning electron microscopy. The principal aims of this investigation were to study in some detail the reactive changes in the retina with particular reference to the response of glia and retinal pigment $\sigma$ epithelium. In addition an attempt was made to N identify the main sites of entry of inflammatory cells N into the vitreous.

\section{Materials and methods}

FIBROBLAST CULTURE AND INJECTION

Fibroblasts were cultured from skin biopsies which $\frac{0}{0}$ were aseptically removed from the rumps of New Zealand white rabbits. ${ }^{5}$ After 2-3 weeks in culture the $\overparen{\mathbb{Q}}$ 
cells were removed by trypsinisation, centrifuged, and resuspended in phosphate-buffered saline (PBS) as previously described. ${ }^{6}$ Cell viability within the suspension of fibroblasts was approximately $98 \%$ as estimated by the trypan blue exclusion method. Approximately 400000 autologous fibroblasts in $\mathbf{0 . 2}$ $\mathrm{ml}$ sterile PBS were injected into the experimental (right) eye of each rabbit via the pars plana. Prior to the injection each experimental eye was softened by a paracentesis of the anterior chamber.

\section{MORPHOLOGY (60 RABBITS)}

The animals were killed at various times after the injection of fibroblasts, ranging from immediate to six months, by an overdose of sodium pentobarbitone. The eyes were enucleated and fixed by immersion into a cold $3 \%$ glutaraldehyde solution in cacodylate buffer. Prior to fixation a slit was made at the equator of the eye to enhance penetration of the fixative. After 24 hours the eyes were dissected, and the vitreal membranes were removed (these were used in other studies). Pieces of limbal tissue, iris, ciliary body up to the ora serrata, optic nerve head, and retina were then postfixed in a $1 \%$ osmium tetroxide solution and dehydrated through a graded series of alcohols. The injection site was not identified in any of our specimens. Tissue for transmission electron microscopy was embedded in either Araldite or Epon (see autoradiography section). Propylene oxide was used as the intermediate fluid. Semithin sections (approximately $1 \mu \mathrm{m}$ ) were cut on an ultramicrotome (Huxley) and stained with a $1 \%$ aqueous solution of toluidine blue. Ultrathin sections $(70 \mathrm{~nm})$ were cut on an automatic ultramicrotome (Ultracut E, Reichert-Jung) and stained with lead citrate and uranyl acetate. The tissues were viewed and photographed in a JEOL $100 \mathrm{C}$ transmission electron microscope. Specimens for scanning electron microscopy, after alcohol dehydration, were dried further in a critical point drier (Polaron), and then the specimens were sputter coated with gold (Polaron). The tissues were examined and photographed in a Hitachi S 520 scanning electron microscope. Any remaining tissue from the eyes was processed for routine paraffin wax histology. The wax sections were stained with haematoxylin and eosin.

\section{IMMUNOHISTOCHEMISTRY (33 RABBITS)}

After the rabbits were killed the eyes were enucleated, fixed in $10 \%$ formal saline, and processed for paraffin wax embedding. Sections (5-8 $\mu \mathrm{m})$ were cut and mounted on glass microscope slides precoated with a solution of $0.1 \%$ poly Llysine.

Three of the rabbits had not been injected with fibroblasts and were used as controls for the staining of normal tissues for the presence of actin and prekeratin.

\section{Actin (13 rabbits)}

The tissues were pretreated with hydrogen peroxide to remove any endogenous peroxidase and normal swine serum to prevent non-specific staining from the link immunoglobulin. Serum containing antiactin antibodies was raised in our laboratory.' The primary antibody was diluted 1:40 with trometamol (Tris) buffered saline (TBS). The pig antirabbit immunoglobulin link and the rabbit peroxidaseantiperoxidase complex were diluted 1:50 with TBS. The substrate for the peroxidase reaction was a $0 \cdot 05 \%$ solution of $3 \cdot 3$-diamino benzidine tetrahydrochloride (DAB) plus $1 \%$ hydrogen peroxide in $0.2 \mathrm{M}$ trometamol solution. Appropriate controls were conducted which have been described previously.'

\section{Prekeratin (23 rabbits)}

A standard immunoperoxidase technique was used to stain the wax sections for the presence of prekeratin. The primary antibody was guinea-pig antiprekeratin to bovine hoof (Miles Scientific, Slough) and was diluted 1:30 with TBS. The peroxidaselabelled antiguinea-pig immunoglobulin was diluted 1:30 with TBS. The substrate for the peroxidase reaction was DAB.

The positive staining of cultured corneal epithelium was used as a control for the presence of prekeratin. ${ }^{13}$

\section{AUTORADIOGRAPHY (23 RABBITS)}

\section{Thymidine}

Twelve rabbits having received an intravitreal injection of fibroblasts for various time periods ( 2 days -10 weeks) were given a further ipsilateral intravitreal injection of $30 \mu \mathrm{Ci}(30 \mu \mathrm{l})$ of [methyl $-{ }^{3} \mathrm{H}$ ] thymidine (Amersham International PLC, Amersham) 24 hours prior to death. One rabbit received radiolabel only and served as a control.

\section{Proline}

Nine rabbits which had been injected with fibroblasts for various time periods (1-10 weeks) were given an injection of $30 \mu \mathrm{Ci}(30 \mu \mathrm{l})$ of $\mathrm{L}-\left[5-{ }^{3} \mathrm{H}\right]$ proline (Amersham International PLC, Amersham), 24 hours prior to death. One rabbit which had the injection of proline without the earlier intravitreal fibroblast injection served as a control.

\section{Tissue processing}

Following death and enucleation the ocular tissues were processed and embedded in Epon as described 


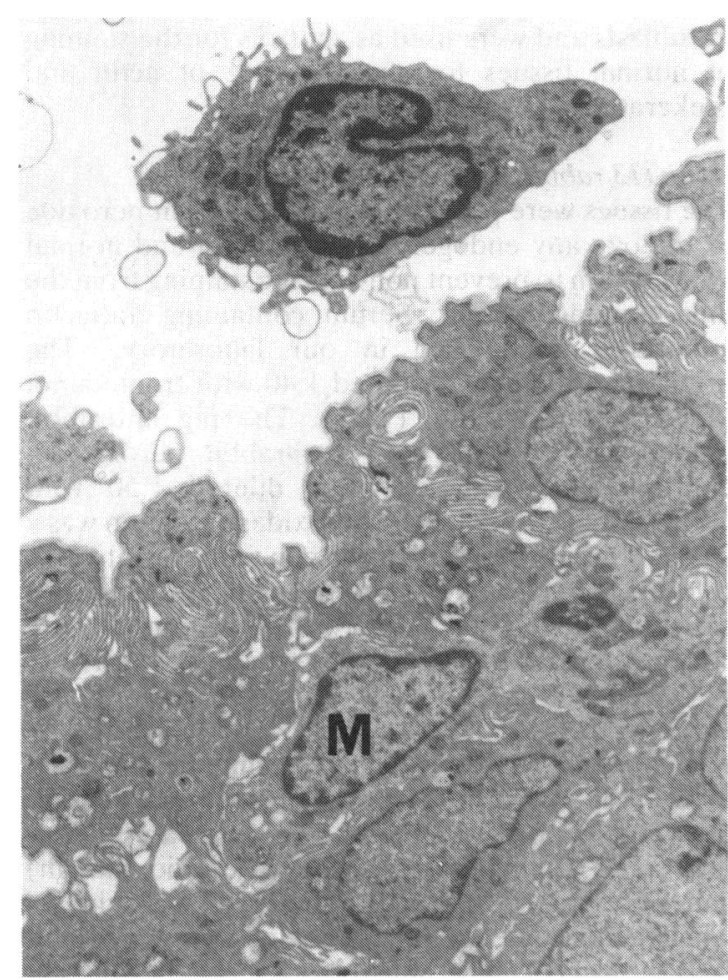

Fig. 1a A transmission electron micrograph of a partially oblique section of epithelium from the posterior portion of the ciliary processes. Six days after the injection of fibroblasts a macrophage (M) is evident within the distended extracellular spaces of the epithelium. $\times 3825$.

earlier. Semithin sections were processed for autoradiography as described by Hitchins and Grierson. ${ }^{6}$ The autoradiographs were left in the dark at $4^{\circ} \mathrm{C}$ for an exposure time of six weeks for ${ }^{3} \mathrm{H}$ thymidine and 11-12 weeks for ${ }^{3} \mathrm{H}$ proline. The autoradiographs were then developed and stained with a $1 \%$ alcoholic solution of toluidine blue at room temperature. The sections were examined under a light microscope.

\section{Results}

IN FLAMMATION

Inflammatory cells invaded the vitreal cavity during the first few days following the intravitreal injection of autologous fibroblasts and were associated with the vitreal proliferations which developed. The inflammatory cells gained entry to the vitreous by two key areas, via the epithelium of the pars plana and pars plicata (Fig. 1a) and the vascular complex associated with the medullary rays of the optic nerve head (Fig. 1b). During the acute stage of inflammation polymorphonuclear leucocytes were prominent

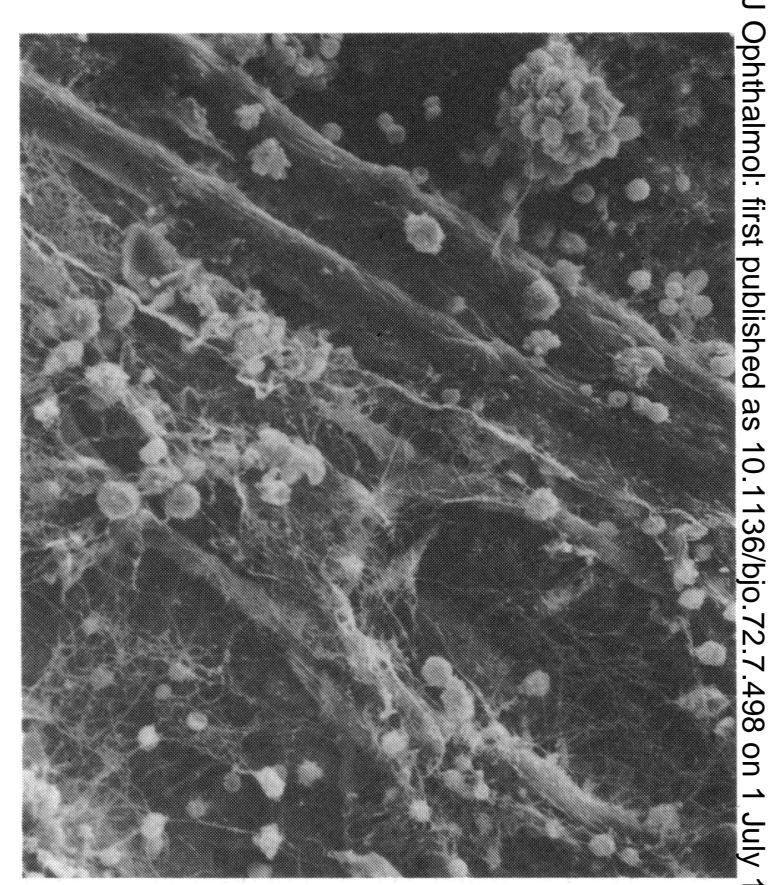

Fig. 1b A scanning electron micrograph showing aggregates of inflammatory cells in close association with the vascular complex on the medullary rays three days after the intravitreal injection of fibroblasts. $\times 407$.

throughout the uvea and vitreous. After one week $\stackrel{\circ}{\circ}$ the infiltrate consisted mainly of lymphocytes and $₫$ macrophages. The mononuclear cells were present $\overrightarrow{\vec{\sigma}}$ until the fourth week, after which they were seen 3 infrequently. The meshwork of the anterior chamber appeared to remain free of inflammatory cells.

\section{VASCULATURE ASSOCIATED WITH THE}

MEDULLARY RAYS

The incorporation of ${ }^{3} \mathrm{H}$ proline was more pronounced in the perivascular cells of the control tissue $\frac{0}{3}$ than at any stage following fibroblast injection (Fig. 2). Fibroblast injection resulted in the vessel basement membranes becoming multilayered, and $\frac{D}{O}$ swollen mitochondria in the endothelium were commonly seen.

INNER RETINAL SURFACE AND EPIRETINAL

MEMBRANE FORMATION

Areas of retinal surface were noted by SEM to be $\mathcal{O}$ denuded of cortical vitreal collagen one week after $\stackrel{0}{=}$ the fibroblast injection. After three weeks small bulges were seen protruding through the inner limiting lamina (ILL) into the vitreal cavity (Fig. 3a). $\frac{0}{0}$ Occasionally evidence of cell processes extending $\frac{\vec{\Phi}}{\mathbb{Q}}$ through the ILL on to the vitreal surface of the retina $\frac{?}{\mathbb{D}}$ 


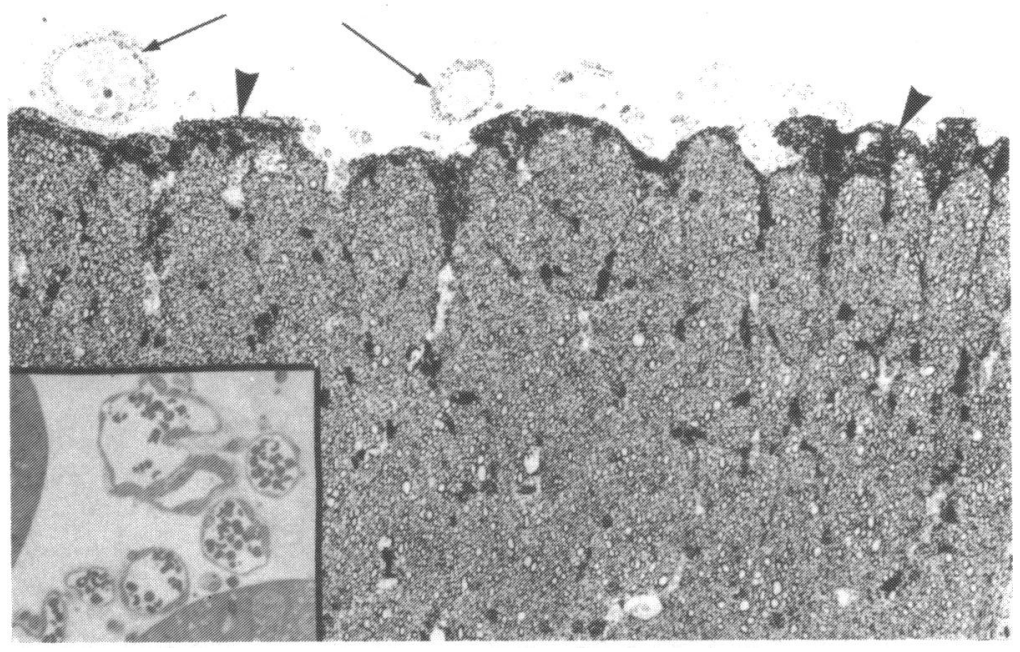

Fig. 2 Autoradiographshowing the incorporation of ${ }^{3} \mathrm{H}$ proline within the control rabbit's optic nerve head. Label was seen particularly in the glia (arrowheads) and the perivascular cells (arrows). $\times 175$. Insert: Autoradiograph four weeks after an intravitreal injection of fibroblasts the incorporation of ${ }^{3} \mathrm{H}$ proline had decreased substantially. $\times 175$.

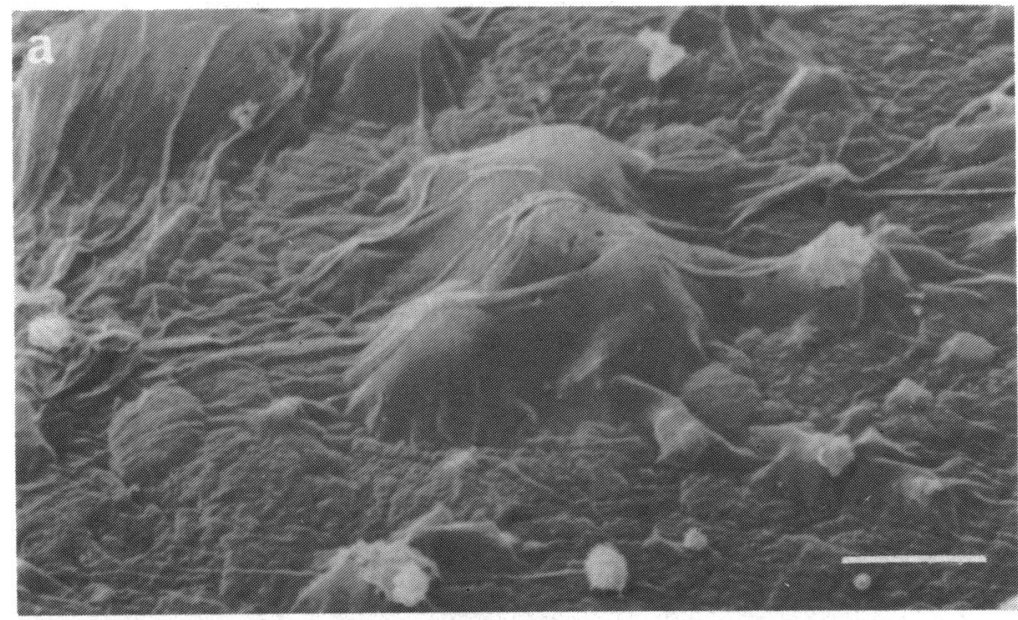

Fig. 3 a: SEM showing bulges on the inner retinal surface three weeks after a fibroblast injection. $\times 700$. b: SEM demonstrating a cell extending its processes through the inner limiting lamina only three days after the injection. $\times 2300$.
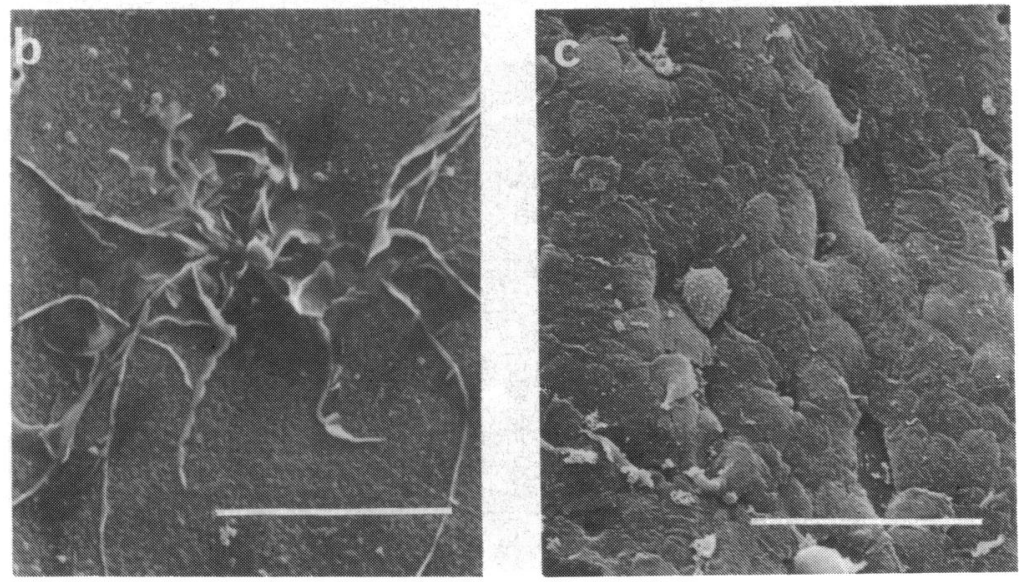

c: SEM of plate-like glia which had formed an epiretinal membrane 10 weeks after the injection of fibroblasts. $\times 460$. Bar markers are (a) $20 \mu \mathrm{m}$, (b) $10 \mu \mathrm{m}$, and (c) $50 \mu \mathrm{m}$. 
Fig. 4a Autoradiographshowing the incorporation of ${ }^{3} \mathrm{H}$ thymidine within the rabbit's retina one week after a fibroblast injection. Clusters of grains (arrowheads) were seen within the nuclei of the cells of the epiretinal membrane $(\mathrm{E})$, nerve fibre, ganglion cell, and inner nuclear layers. $\times 336$. Insert: High power of grain cluster within the nucleus of a cell from the inner nuclear layer. $\times 480$.

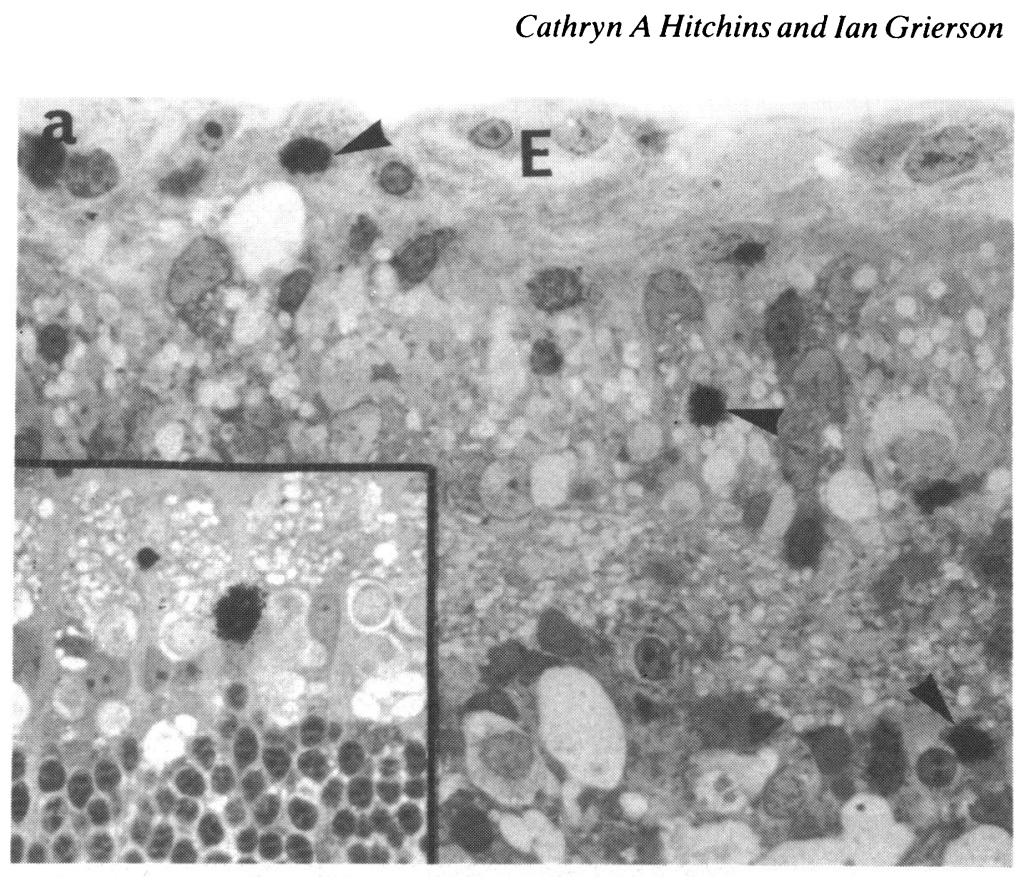

was found as early as three day after the injection (Fig. 3b). At the 10-week stage cells were clearly visible on the retinal surface, and often these cells contributed to foci of monlayers or even multilayers of plate-like glial cells (Fig. 3c).

Incorporation of ${ }^{3} \mathrm{H}$ thymidine, as indicated by large clusters of silver grains, was not found within the nuclei of the retinal cells in the control tissue. However, one week after the injection of fibroblasts sporadic nuclear incorporation of ${ }^{3} \mathrm{H}$ thymidine was evident within the retina, particularly in the inner nuclear layer (Fig. 4a). Also at one week labelled nuclei were a feature of the newly developing epiretinal membranes (Fig. 4a). Labelled nuclei were

Fig. 4b Autoradiographshowing the diffuse pattern and low level of ${ }^{3} \mathrm{H}$ proline incorporation within the degenerating retina $(\mathrm{R})$ and overlying epiretinal membrane (E) two weeks after a fibroblast injection. Note two cells of the epiretinal membrane with high levels of incorporation (arrow). $\times 768$.

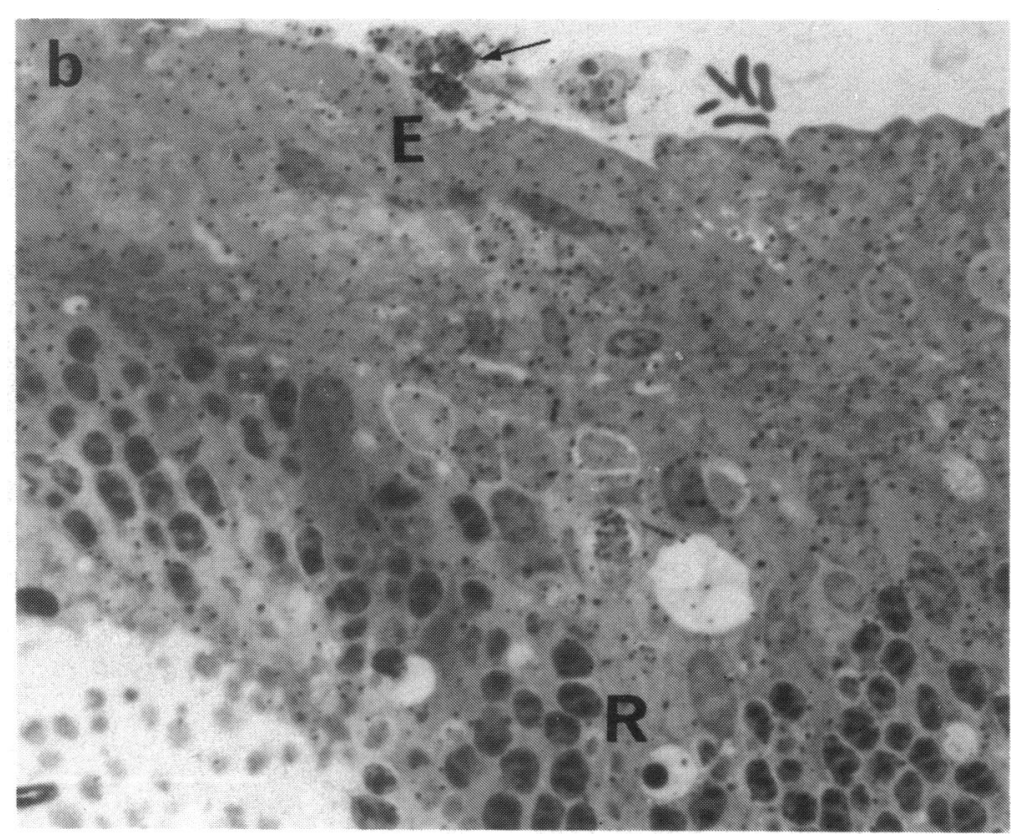




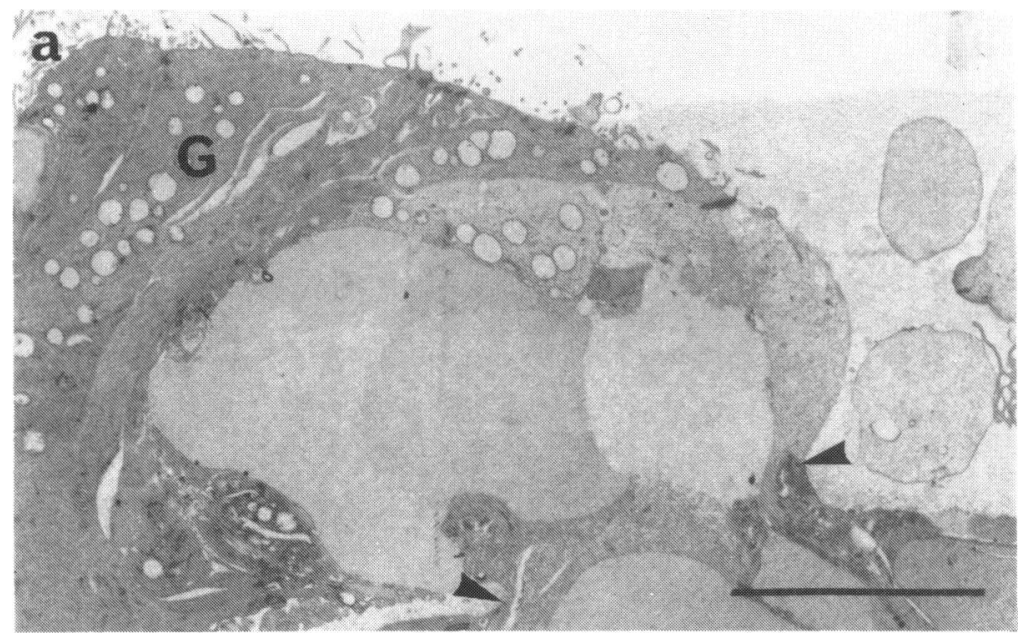

Fig. 5a TEMsofepiretinal membranes six weeks afteran * injection of fibroblasts. a: Glial-like tissue $(\mathrm{G})$ with surface microvilli, which had protruded through a break in the inner limiting lamina (arrowheads). $\times 2480$.

evident in the retina and epiretinal membranes up to six weeks, but by 10 weeks ${ }^{3} \mathrm{H}$ thymidine incorporation into nuclei was not.common. Over the period from one to 10 weeks labelling in the majority of the cells of the epiretinal membranes was low and diffuse, but occasional cells did'show high incorporation levels (Fig. 4b). The épiretinal membranes consisted mainly of glial cells, while fibroblasts and associated collagen were also noted. The glial cells were identified on the basis of their abundant cytoplasmic intermediate filaments, apical surface microvilli, and basement material (Figs. 5a, b). Adhering junctions were seen frequently joining adjacent glial cells (Fig. 5b).

\section{RETINA}

Immunohistochemical staining for actin in the retina gave a similar result to that found in the normal tissue. The inner and outer plexiform layers, the inner segments of the photoreceptor cells, and some cells in the nerve fibre layer showed a moderate positive reaction to the antiactin antibodies.

In the control retina the incorporation of ${ }^{3} \mathrm{H}$ proline was pronounced, particularly in the central retina. Uptake of label was prominent within the vasoglial connections, many cells of the inner nuclear layer and the ganglion cells (Fig. 6a). But in the experimental tissue one week after the fibroblast injection the level of proline incorporation was much lower, though some preferential incorporation was still evident. In the detached retina the label was at a very low level and was scattered diffusely throughout the various layers.(Figs. $4 b, 6 b, c)$.

Three weeks after the injection of fibroblasts most

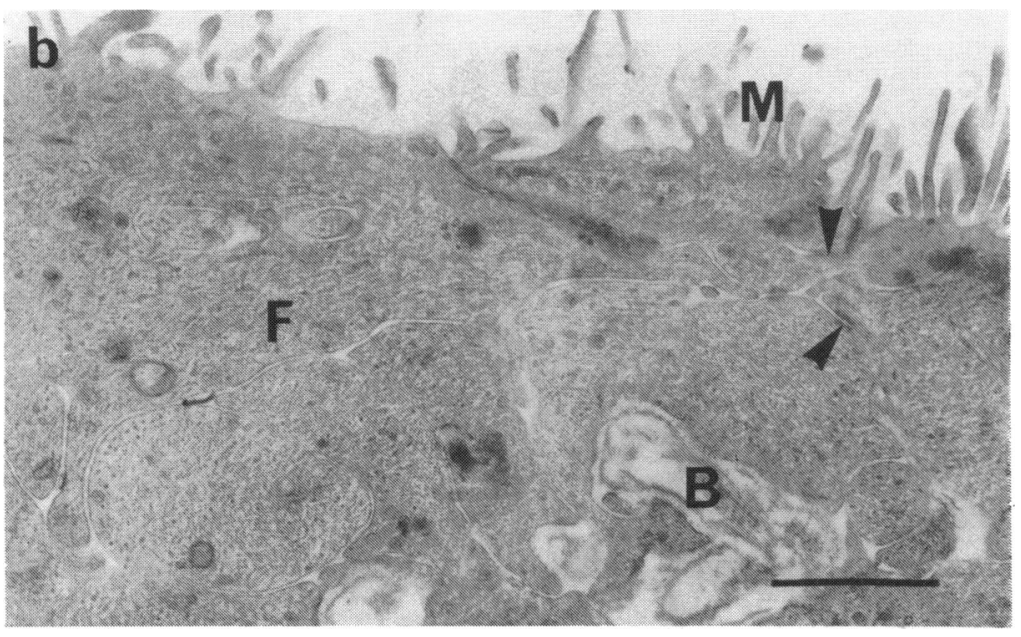

Fig. 5b At higher power one of the cells demonstrated intermediate filaments (F), basement material (B), adhering junctions (arrowheads) as well as surface microvilli (M). $\times 16550$. Bar markers are (a) $10 \mu \mathrm{m}$ and (b) $1 \mu m$. 
Fig. 6a Autoradiograph of the control rabbit's retina showing the incorporation of ${ }^{3} \mathrm{H}$ proline.

Preferential uptake was visible in the inner nuclear (arrowheads), ganglion, and nerve fibre (arrows) layers. $\times 355$

Fig. 6b Two weeks after a fibroblast injection the outer segments could not be seen, with only remnants of the inner segments remaining (arrowheads). There were oedematous areas in the ganglion cell layer (arrows). $\times 355$. Insert: High power showing evidence of proline incorporation which was of a low level. $\times 515$.

Fig. 6c Fourweeks aftera fibroblast injection subretinal macrophages (the smaller migratory cells) were observed at the outer surface (arrowheads) and swelling was seen throughout the retina. Glial tissue $(\mathrm{G})$ appeared to have proliferated on to the outer retinal surface. $\times 355$.
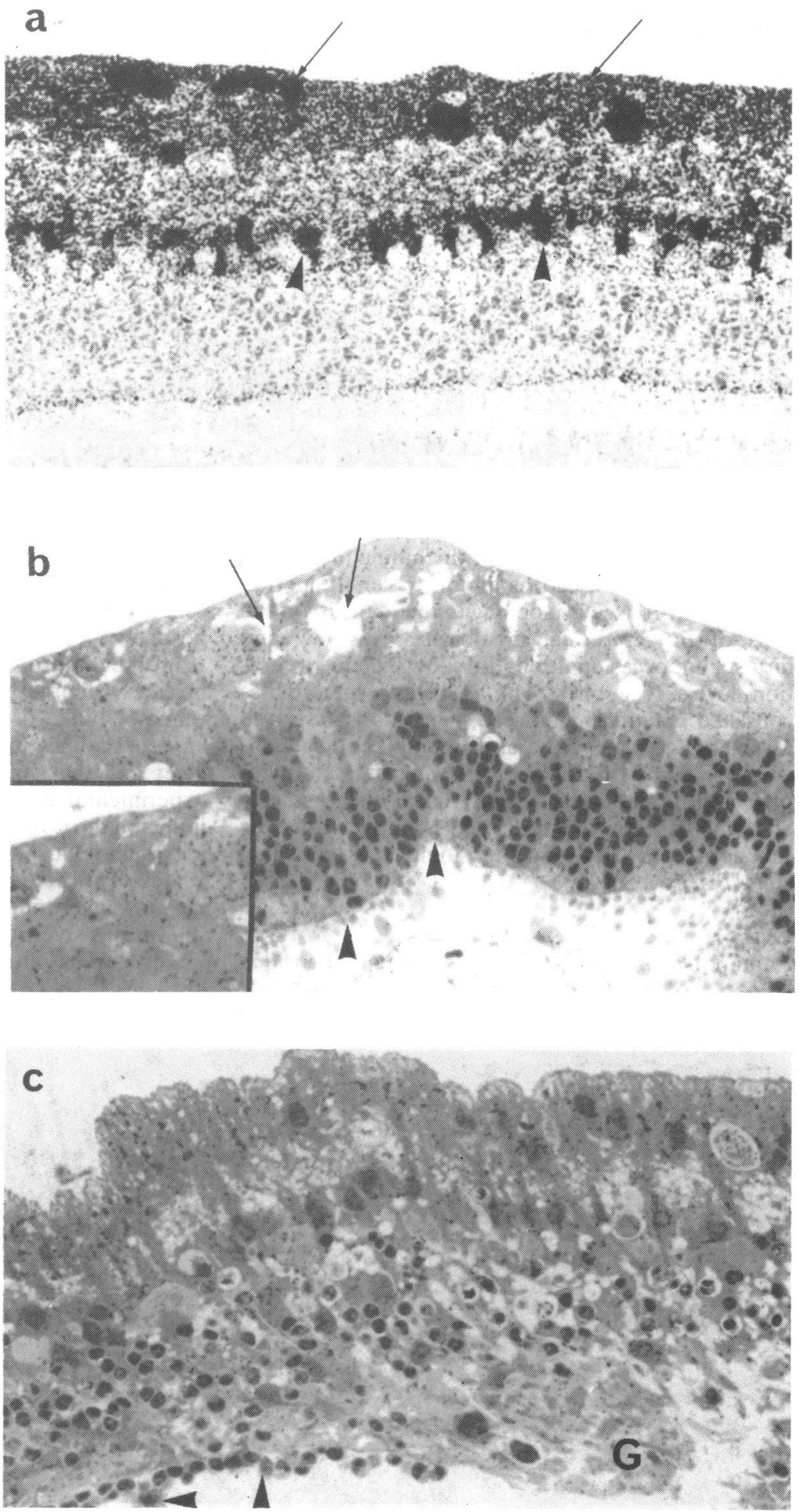
of the rabbits had a retinal detachment. By this time the most marked structural change was the gradual loss of the photoreceptor cells, which began with the loss of the outer segments and then the inner segments. (Fig. 6b). A rapid decline in retinal organisation and increased oedema occurred between two and four weeks following the injection of fibroblasts (Figs. 6b, c). Oedema progressed throughout the retinal layers with the increased period of detachment.

RETINAL PIgMENT EPITHELIUM (RPE)

Following detachment of the neural retina from the pigment epithelium the RPE had lost its hexagonal arrangement (Fig. 7a) and had become rounded (Fig. 7b). The morphological alterations to the RPE increased with the duration of the retinal detachment. The apical processes had become shorter and were found on all free surfaces (Figs. 7a, b). Widening and shortening of the basal infoldings were seen, and the mitochondria were swollen (Fig. 7b). Some of the cells appeared to be more rounded or 'scalloped' than the surrounding cells. These cells gradually became detached from the monolayer (Fig. $7 b$ ). Two different sizes of migratory cells were evident in the subretinal space, and these could best be seen by SEM. The smaller cells had larger surface microvilli, which were less frequent than the small, abundant surface microvilli seen on the larger cells (Fig. 7a).

Under a detachment the 'scalloped' RPE cells and some of the larger cells in the subretinal space gave an intense positive staining reaction to prekeratin and actin (Fig. 8a). The reaction to the prekeratin antibodies was greater than that found in RPE attached to the neural retina in the normal tissue.

Both the large and small cells in the subretinal space were found to incorporate ${ }^{3} \mathrm{H}$ thymidine in their nuclei (Fig. 8b). The incorporation of ${ }^{3} \mathrm{H}$ proline in the RPE was lower than that seen in the control tissue.

SUBRETINAL MEMBRANE FORMATION

Subretinal membranes both on the exposed outer retinal surface (Fig. $8 \mathrm{c}$ ) and on Bruch's membrane were found beneath a detached retina at various times after an injection of fibroblasts. The cells on the outer retinal surface appeared to be glia which had migrated from the retina (Fig. $8 \mathrm{c}$ ), while the RPE cells had become elongated and several layers deep. Both the disorganised retina and the subretinal membranes showed low and diffuse levels of ${ }^{3} \mathrm{H}$ proline incorporation (Fig. 8c).

The proliferations associated with both of the retinal surfaces were found to contain rounded cells, which stained more intensely for actin than the surrounding tissue (Fig. 9a). In addition some cells within the epiretinal and subretinal membranes stained positively for prekeratin (Figs. 9b, c).

\section{Discussion}

The inflammatory response evoked in both the anterior and posterior chambers following an intravitreal injection of autologous fibroblasts has been described previously. ${ }^{56}$ In the present investigation
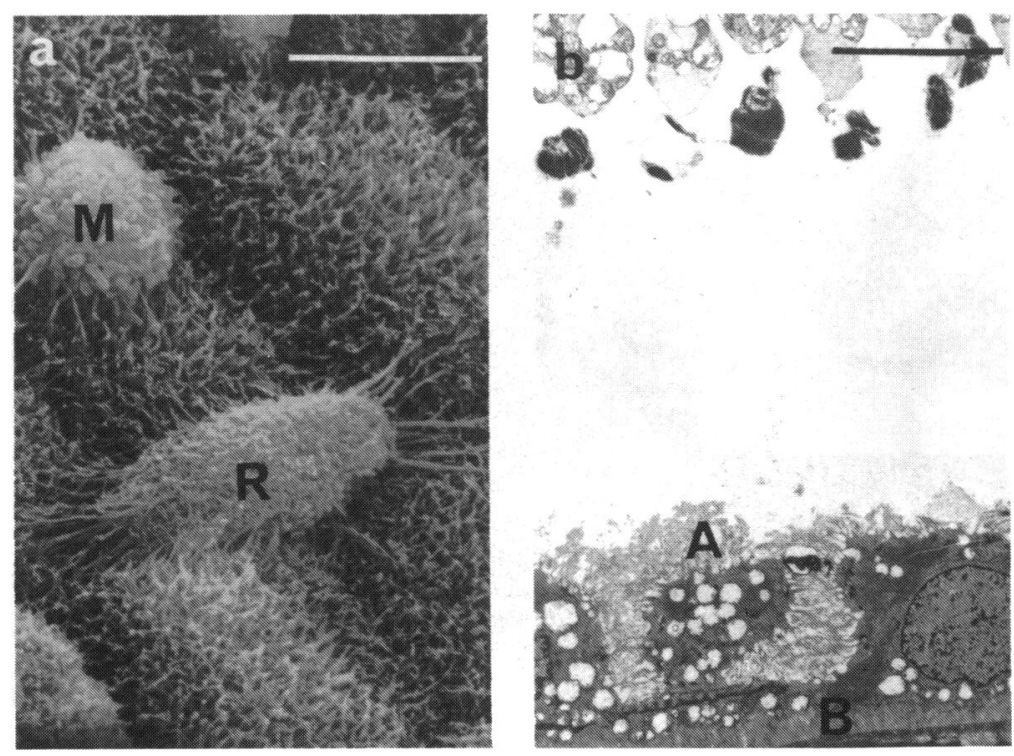

Fig. 7a SEM of the RPE under a detached retina four weeks after a fibroblast injection. The apical surfaces of the cells had become 'scalloped'. Some of the larger cells (R) seemed to be detaching from the monolayer and were presumed to be RPE. Smaller migratory cells (M) with large microvilli were also seen. $\times 1855$.

Fig. 7b TEM of a scalloped RPE layer beneath a detached retina six weeks after an injection of fibroblasts. The cells had abundant and disorganised apical processes (A), while the basal portion (B) had widened and shortened infoldings. $\times 1630$. Bar markers are (a) $10 \mu \mathrm{m}$ and (b) $10 \mu \mathrm{m}$. 
Fig. 8a The RPE (arrowheads) under a detached retina stained positively for prekeratin when stained by an indirect

immunoperoxidase technique. $\times 355$.

Fig. 8b Autoradiograph of ${ }^{3} \mathrm{H}$ thymidine within the nuclei of both the large (arrow) and small (arrowheads) subretinal, migratory cells. $\times 395$.

Fig. 8c Autoradiographshowing a diffuse pattern and low level of ${ }^{3} \mathrm{H}$ proline incorporation within a subretinal membrane (S), four weeks after a fibroblast injection. $\times 475$. Insert: High power showing silver grains of proline incorporation. $\times 595$.
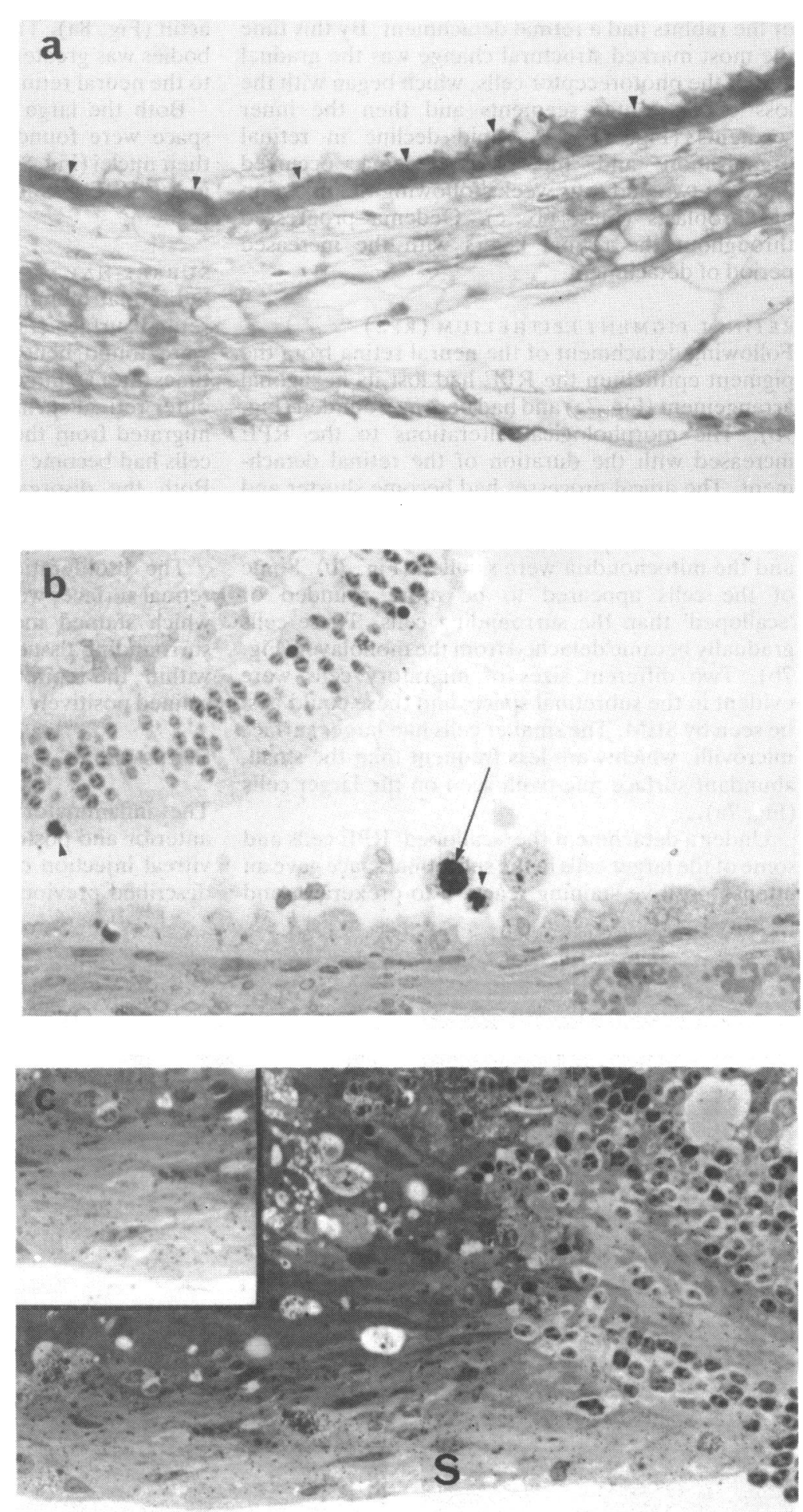
the inflammatory cell infiltrate was found to gain entry into the vitreous via the pars plana and the vascular complex associated with the optic nerve head. Inflammatory cells were found also within the choroid and beneath the detached retina.

The formation of new vessels within the vitreal proliferations $^{5}$ and in the optic disc region ${ }^{10} 11$ was most likely to have been promoted by the release of 'angiogenic' or 'vasoproliferative' factors arising from retinal ischaemia ${ }^{14-16}$ though other factors may have been involved.

The structural changes within the vessels and the perivascular cells were characteristic effects of ischaemia. ${ }^{17}$ The accumulation of basement material around the vessels implied endothelial cell degeneration and regeneration with secondary pericyte degeneration. ${ }^{1819}$ The low levels of ${ }^{3} \mathrm{H}$ proline incorporation in perivascular cells is difficult to interpret. These were not 'pulse chase' experiments, so that we do not know whether the low levels represented a rapid turnover of radiolabelled proline or a poor uptake. However, there is undoubtedly a change in metabolic activity in comparison with the perivascular cells in the control tissue.

The development of both epiretinal and subretinal membranes was observed after an intravitreal injection of fibroblasts; these proliferations were associated with a tractional retinal detachment. Fibroblast-like cells, glial-like cells, epithelium-like cells, and collagen were identified within the epiretinal membranes. Indeed low levels of ${ }^{3} \mathrm{H}$ proline were seen within all the cell types associated with the epiretinal membranes. However, the level of incorporation was low, though new collagen was seen in many of the epiretinal membranes examined. This unexpected result could be explained by the time of proline administration being too late, that is, beyond the time when collagen precursors were being synthesised.
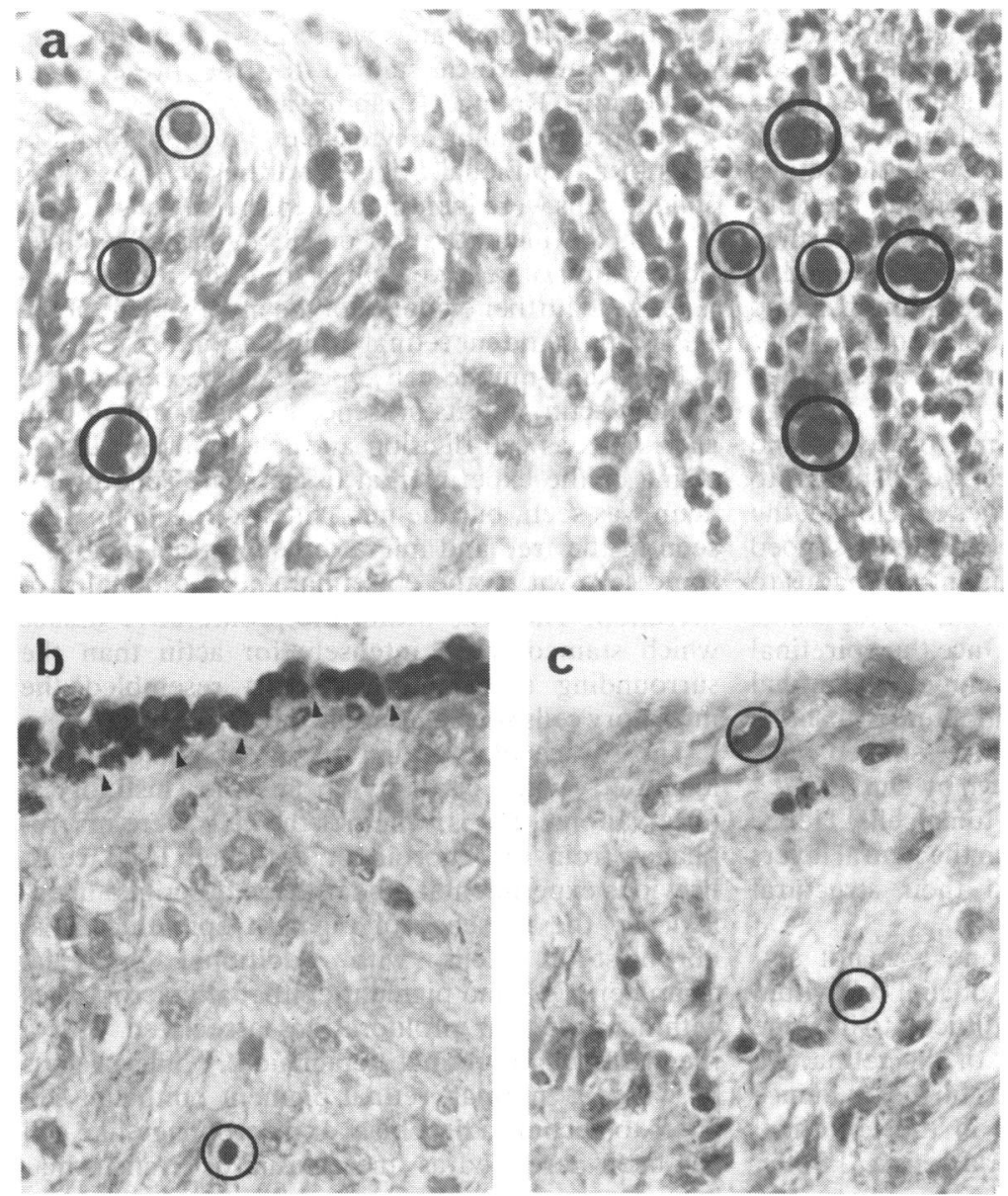

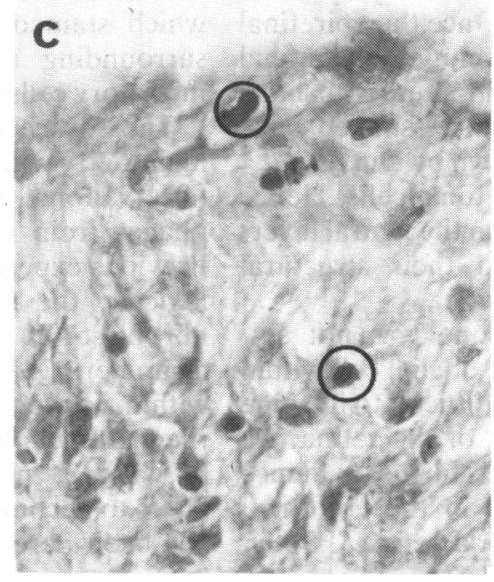

Fig. 9 a: Some large migratory cells (circled) within an epiretinal membrane were found to stain strongly for actin (counterstained with haematoxylin). $\times 510$. $\mathrm{b}$ and $\mathrm{c}$ : Some of the migratory cells (circled or arrowheads) within epiretinal membranes were found to stain positively for prekeratin (no counterstain).

Immunohistochemical staining by the peroxidase-antiperoxidase technique. $\times 510$. 
The glial cells which had migrated on to the retinal surfaces had abundant cytoplasmic filaments similar to fibrous astrocytes, but the cells tended to be platelike or spindle-shaped. Green ${ }^{20}$ described glial cell proliferation as a 'reparative and degenerative process'. In the present study glial cells were seen on the exposed outer retinal surface. It seemed likely that Müller cells formed these subretinal proliferations, as they were plate-like cells similar to those described by Burke and Foster when cells from the retina were grown in culture. ${ }^{21}$ The migration of accessory glia through the retina to the subretinal space seemed an unlikely event.

The protrusion of retinal cells on the inner retinal surface has also been suggested to be a reparative response to breaks in the ILL, caused by substances 'foreign' to the vitreous..$^{22}$ Grierson and Forrester ${ }^{3}$ proposed that the release of lytic enzymes, from intravitreally injected fibroblasts which had died, caused the rupture of the vitreous face, resulting in posterior vitreous detachment, thus ensuring the availability of the retinal surface as a scaffold for cell migration and proliferation. Nevertheless we found that, although the injection of fibroblasts caused posterior detachment and liquefaction of the vitreal gel, damage to the ILL on the vitreal surface was not seen. In contrast the bulges seen on the retinal surface appeared to originate from beneath the ILL, which indicated that the retinal cells were pushing their way through. Eventually cells were observed to come through the subsequent deficits in the ILL and then were able to migrate and proliferate on the inner retinal surface to form epiretinal membranes. When the retinal cells initially began to protrude through the ILL, they had many cytoplasmic processes and intermediate filaments and hence were similar to fibrous astrocytes. As the membranes developed, the glial cells had become plate-like or spindle-shaped but still retained a cytoplasmic content analogous to fibrous astrocytes, that is, abundant cytoplasmic filaments with few organelles. ${ }^{23}{ }^{24}$ Once the epiretinal and subretinal membranes had developed, the retinal glia within these proliferations had altered in shape from astrocytic to plate-like or spindle-shaped cells. A similar change in shape was shown by Duffy et al. ${ }^{25}$ to occur in tissue cultured astrocytoma cells. Hence the movement of the glial cells from the neural layers of the retina may have caused their structural alteration.

Unfortunately, morphology alone was not sufficient to reveal the definitive type of glial cell within the membranes. Even though it is difficult to imagine how Müller cells can migrate out of the retina, we consider that this study has provided further evidence to indicate that such is the case in the epiretinal membranes found in the peripheral retina. Firstly, the protrusions on the inner retinal surface which were seen in the initial stages of epiretinal membrane formation were far too numerous for them to be astrocytic glia. Indeed it was shown previously that only the medullary ray areas of the rabbit retina contained astroglia, whereas Müller cells were identified throughout the retina. ${ }^{26}$ Secondly, the majority of ${ }^{3} \mathrm{H}$ thymidine incorporation within the retina was located in the inner nuclear layer, implying DNA synthesis within the Müller cell nuclei which are situated there. On the other hand the possibility of astrocytic glia being involved in epiretinal membranes in the medullary ray areas could not be dismissed.

Sternberg and Machemer $^{27}$ suggested that human subretinal membranes were composed mainly of pigment epithelial cells, whereas glial cells were prominent in subretinal membranes produced in experimental animals models. In the present study glial cells were identified histologically within the subretinal membranes which developed after an intravitreal injection of autologous fibroblasts. In addition the membranes were shown definitively to contain cells which stained for the presence of prekeratin. Runnger-Brändle and Gabbiani ${ }^{28}$ described prekeratin as a cytoskeletal protein found in cells of an epithelial origin, and thus the positively stained cells were identified as epithelial cells.

Both the incorporation of ${ }^{3} \mathrm{H}$ thymidine and the observation of cells detaching from the RPE monolayer gave further evidence of the involvement of the RPE cells in the subretinal proliferation.

Many non-muscle cell types have been shown to contain actin, and its presence has been linked with such roles as cell division and locomotion. ${ }^{29}$ In the retina of the experimental tissue some staining for actin was seen, but the most intense reactions were seen in the free and migratory subretinal cells and some cells within the epiretinal and subretinal proliferation. The cells within the proliferative tissues which stained more intensely for actin than the surrounding elongated glial cells resembled the migratory cells seen in the subretinal space.

The source of the migratory cells could not be identified with certainty from the histological observations, that is, whether the cells were macrophages from the choroid or detached RPE cells. Previous experimental models have described histologically the presence of pigment epithelial cells, fibroblast-like cells with additional epithelial characteristics, and pigment epithelial macrophages within intraocular proliferations associated with a rhegmatogenous retinal detachment. ${ }^{30}$ The process by which a 'normal' retinal pigment epithelial cell alters to become a fibroblast or macrophage-like cell has been described as 'metaplasia' or 'transforma- 
tion' by others. ${ }^{31-33}$ On the other hand cells of haematogenous origin have been seen to migrate from the choroid to the vitreous following injury to the vitreous ${ }^{34}$ and retina ${ }^{35}$ However, we have shown immunohistochemically the presence of large, rounded cells which stained positively for the presence of prekeratin and therefore were identified as epithelial cells. Hence a proportion of the rounded migratory cells within the retinal proliferations was apparently of an epithelial origin. Therefore some of the largest migratory cells, which have been seen in the past within the retina, ${ }^{3436}$ and within periretinal proliferations in the present study, were identified by immunohistochemistry as cells of an epithelial origin. However, other cells both within the retinal proliferation and the subretinal space were identified as 'true' macrophages (of reticuloendothelial origin) on the basis of their smaller size and their surface microvilli, which differed from those of the RPE. A proportion of both the larger rounded RPE cells and the inflammatory cells stained for actin and incorporated ${ }^{3} \mathrm{H}$ thymidine. The detached retinae which occurred in all the rabbits' eyes following an intravitreal injection of fibroblasts showed pathological changes associated with ischaemia which were similar to those described by Johnson ${ }^{37}$ and Johnson and Foulds. ${ }^{17}$

The overall deterioration of the detached retina was mirrored by the very low and diffuse levels of ${ }^{3} \mathrm{H}$ proline incorporation which were seen in comparison with the normal tissue. Depression of proline incorporation within the Müller cells is consistent with their loss of function during prolonged periods of retinal detachment. The results compared favourably with those of Machemer and Buettner ${ }^{38}$ when the differences in technique, dosage, and isotope are taken into account.

The morphological changes seen within the RPE following retinal detachment induced by the injection of fibroblasts were similar to the changes found after high pressure induced ischaemia ${ }^{17}$ and experimental retinal detachment ${ }^{36}$ in the rabbit. The nuclear incorporation of ${ }^{3} \mathrm{H}$ thymidine within the attached and detached RPE cells provided evidence of DNA synthesis. DNA synthesis has also been demonstrated in the RPE of the owl monkey ${ }^{311}$ and $\mathrm{cat}^{39}$ following retinal detachment. Anderson et al. ${ }^{39}$ believed that the loss of metabolic exchange between the separated neural retina and RPE brought about the 'dedifferentiation' and proliferation of the RPE cells.

This work was supported by the Wellcome Trust (grant no. 10998/1.5) and the Frost Charity Trust.

We thank Mrs P Goodwin for her secretarial assistance.

\section{References}

1 Algvere P, Kock E. Experimental fibroplasia in the rabbit vitreous. Retinal detachment induced by autologous fibroblasts Graefes Arch Clin Exp Ophthalmol 1976; 199: 215-22.

2 Sugita G, Tano Y, Machemer R, Abrams G, Claffin A Fiorentino $\mathrm{G}$. Intravitreal autotransplantation of fibroblasts Am J Ophthalmol 1980; 89: 121-30.

3 Grierson I, Forrester J. Vitreous haemorrhage and vitreal membranes. Trans Ophthalmol Soc UK 1980; 100: 140-50.

4 Grierson I, Rahi AHS. Structural basis of contraction in vitreal fibrous membranes. Br J Ophthalmol 1981; 65: 737-49.

5 Hitchins CA, Grierson I, Hiscott PS. The effects of injections of cultured fibroblasts into the rabbit vitreous. Graefes Arch Clin Exp Ophthalmol 1985; 223: 237-49.

6 Hitchins CA, Grierson I. Experimental scar membranes in the rabbit's vitreous. An autoradiographic and quantitative morphological study. Acta Ophthalmol (Kbh) 1985; 63: 557-66.

7 Hitchins CA, Grierson I, Rahi AHS. Contraction of scar tissue in the rabbit vitreous. Connect Tissue Res 1986; 15: 123-40.

8 Wiedemann P, Sorgente N, Ryan SJ. Proliferative vitreoretinopathy: the rabbit cell injection model for screening of antiproliferative drugs. J Pharmacol Methods 1984; 12: 69-78

9 Machemer R, Sugita G, Tano Y. Treatment of intraocular proliferation with intravitreal steroids. Trans Am Ophthalmol Soc 1979; 77: 171-80.

10 Tano Y, Chandler DB, Machemer R. Retinal neovascularisation after intravitreal fibroblast injection. Am J Ophthalmol 1981;92: 103-9.

11 Tano Y, Chandler DB, Machemer R. Vascular casts of experimental neovascularisation. Am J Ophthalmol 1981; 92: 110-20.

12 Moorhead LC. Effects of beta-aminopropionitrile after posterior penetrating injury in the rabbit. Am J Ophthalmol 1983; 95: 97-109.

13 Hitchins CA. The morphological effects of the injection of cultured fibroblasts into the vitreous of the rabbit. $\mathrm{PhD}$ thesis, University of London: 1986

14 Michaelson DC. The mode of development of the vascular system of the retina, with some observations on its significance for certain retinal diseases. Trans Ophthalmol Soc UK 1948; 68: 137-80.

15 Ashton N. Some aspects of the comparative pathology of oxygen toxicity in the retina. Br J Ophthalmol 1968; 52: 505-31.

16 Patz A. 1. Studies on retinal neovascularisation. Friedenwald lecture. Invest Ophthalmol Vis Sci 1980; 19: 1133-8.

17 Johnson NF, Foulds WS. The effects of total acute ischaemia on the structure of the rabbit retina. Exp Eye Res 1978; 27 45-59.

18 Dvorak AM, Mihm MC, Dvorak HF. Morphology of delayedtype hypersensitivity reactions in man. II. Ultrastructural alteration affecting the microvasculature and the tissue mast cells. $L a b$ Invest 1976; 34: 179-91.

19 Green WR, Quigley HT, de la Cruz Z, Cohen B. Parafoveal retinal telangiectasis. Trans Ophthalmol Soc UK 1980; 100: 162-70.

20 Green WR. Retina. In: Spencer WH, ed. Ophthalmic pathology an atlas and textbook. Philadelphia, London, Toronto: Saunders, 1985; 2: 170 .

21 Burke JM, Foster SJ. Culture of adult rabbit retinal glial cells methods and cellular origin of explant outgrowth. Curr Eye Res 1984; 3: 1169-78.

22 Foos RY. Vitreoretinal juncture-simple epiretinal membranes. Graefes Arch Clin Exp Ophthalmol 1974; 189: 231-50.

23 Luse SA. Ultrastructure of the brain and its relation to transpor of metabolites. In: Korey SR, Pope A, Robins E, eds. Ultra structure and metabolism of the nervous system. Baltimore: Williams and Wilkins, 1962: 1-26.

24 Bloom W, Fawcett DW. A textbook of histology. Philadelphia, London, Toronto: Saunders, 1968: 117-26.

25 Duffy PE, Huang Y-Y, Rapport MM. The relationship of glial 
fibrillary acidic protein to the shape, motility and differentiation of human astrocytoma cells. Exp Cell Res 1982; 139: 145-57.

26 Schnitzer J. Distribution and immunoreactivity of glia in the retina of the rabbit. J Comp Neurol 1985; 240: 128-42.

27 Sternberg P, Machemer R. Subretinal proliferation. Am J Ophthalmol 1984; 98: 456-62.

28 Runnger-Brändle E, Gabbiani G. The role of cytoskeletal and cytocontractile elements in pathologic processes. Am J Pathol 1983; 110: 361-92.

29 Goldman RD, Knipe DM. Functions of cytoplasmic fibers in non-muscle cell motility. Cold Spring Harbor Symp Quant Biol 1973; 37: 523-34.

30 Machemer R, Laqua H. Pigment epithelium proliferation in retinal detachment (massive preretinal proliferation). Am J Ophthalmol 1975; 80: 1-23.

31 Mandelcorn MS, Machemer R, Fineberg E, Hersch SB. Proliferation and metaplasia of intravitreal retinal pigment epithelium cell autotransplants. Am J Ophthalmol 1975; 80: 227-37.

32 Müller-Jensen K, Mandelcorn MS. Membrane formation by autotransplanted retinal pigment epithelium. Med Probl Ophthalmol 1975; 15: 228-34.
33 Radtke ND, Tano Y, Chandler D, Machemer R. Simulation of MPP by autotransplantation of RPE in rabbits. Am J Ophthalmol 1981; 91: 76-87.

34 Burke JM, Smith JM. Retinal proliferation in response to vitreous hemoglobin or iron. Invest Ophthalmol Vis Sci 1981; 20: 582-92.

35 Gloor BP. On the question of origin of macrophages in the retina and the vitrcous following photocoagulation (autoradiographic investigation by means of ${ }^{3} \mathrm{H}$-thymidine). Graefes Arch Clin Exp Ophthalmol 1974; 190: 183-94.

36 Johnson NF, Foulds WS. Observations on the retinal pigment epithelium and retinal macrophages in experimental retinal detachment. BrJ Ophthalmol 1977; 61: 564-72.

37 Johnson NF. Effects of acute ischaemia on the structure of the rabbit retina. Trans Ophthalmol Soc UK 1974; 94: 394-405.

38 Machemer R, Buettner H. Experimental retinal detachment in the owl monkey. IX. Radioautographic study of protein metabolism. Am J Ophthalmol 1972; 73: 377-89.

39 Anderson DH, Stern WH, Fisher SK, Erickson PA, Borgula GA. The onset of pigment epithelial proliferation after retinal detachment. Invest Ophthalmol Vis Sci 1981; 21: 10-6.

Accepted for publication 18 May 1987. 